\title{
The Metabolic Implications of Glucocorticoids in a High-Fat Diet Setting and the Counter-Effects of Exercise
}

\author{
Emily C. Dunford and Michael C. Riddell * \\ School of Kinesiology and Health Science, Faculty of Health, Muscle Health Research Center and Physical \\ Activity and Chronic Disease Unit, York University, 4700 Keele Street, Toronto, ON M3J 1P3, Canada; \\ edunford53@hotmail.com \\ * Correspondence: mriddell@yorku.ca; Tel.: +1-416-736-2100; Fax: +1-416-736-5774 \\ Academic Editor: Peter Meikle \\ Received: 2 November 2016; Accepted: 30 November 2016; Published: 5 December 2016
}

\begin{abstract}
Glucocorticoids (GCs) are steroid hormones, naturally produced by activation of the hypothalamic-pituitary-adrenal (HPA) axis, that mediate the immune and metabolic systems. Synthetic GCs are used to treat a number of inflammatory conditions and diseases including lupus and rheumatoid arthritis. Generally, chronic or high dose GC administration is associated with side effects such as steroid-induced skeletal muscle loss, visceral adiposity, and diabetes development. Patients who are taking exogenous GCs could also be more susceptible to poor food choices, but the effect that increasing fat consumption in combination with elevated exogenous GCs has only recently been investigated. Overall, these studies show that the damaging metabolic effects initiated through exogenous GC treatment are significantly amplified when combined with a high fat diet (HFD). Rodent studies of a HFD and elevated GCs demonstrate more glucose intolerance, hyperinsulinemia, visceral adiposity, and skeletal muscle lipid deposition when compared to rodents subjected to either treatment on its own. Exercise has recently been shown to be a viable therapeutic option for GC-treated, high-fat fed rodents, with the potential mechanisms still being examined. Clinically, these mechanistic studies underscore the importance of a low fat diet and increased physical activity levels when individuals are given a course of GC treatment.
\end{abstract}

Keywords: glucocorticoids; high-fat diet; exercise; skeletal muscle; liver; adipose; metabolism

\section{Introduction}

Glucocorticoids (GCs) are a classification of steroid hormones, naturally produced by activation of the hypothalamic-pituitary-adrenal (HPA) axis, that are responsible for mediating both the immune system and energy metabolism. Over the past six decades, synthetic GCs have been established as an integral component of hematological cancer therapy [1] and are also used for the treatment of a variety of inflammatory conditions and diseases [2,3]. It is estimated that $1.0 \%-2.5 \%$ of the population of the United States aged $\geq 20$ years ( 2,513,259 persons) are prescribed oral GCs [4-7]. Unfortunately, chronic or high dose GC administration is associated with numerous side effects such as steroid-induced skeletal muscle loss (i.e., myopathy) [8], peripheral insulin resistance [9], visceral adiposity [10], and diabetes development [11]. GCs are often associated with excessive weight gain in humans and in animals [12], a feature that may be linked, at least in part, to an increased desire for energy dense "comfort" foods (e.g., high fat, simple sugars) [13,14]. A number of recent rodent studies have begun to investigate the relationship between poor dietary choices, such as a diet high in fat (HFD), in combination with chronic or high dose GC administration. It is possible that patients who are taking exogenous GCs could be more susceptible to poor food choices, but the effect of increasing fat consumption in combination with elevated exogenous GCs has only recently been investigated. 
This paper will summarize the available information regarding the metabolic implications associated with the collective effects of elevations in GCs and a HFD (i.e., a diet specifically enriched with saturated fats). This information is critically important and clinically relevant as the number of patients taking exogenous GCs is rising and underscores the importance of a low fat diet when individuals are given a course of GC treatment.

\section{Overview of GCs in Health and Disease}

Several cardiometabolic diseases (i.e., central obesity, type 2 diabetes, type 1 diabetes, metabolic syndrome, and pre-diabetes) are associated with elevations in GC concentrations [15]. The elevation in GCs, which may be the result of the disease itself or may be driving the disease progression, impacts a number of metabolic and behavior elements [16]. The glucocorticoid/glucocorticoid receptor (GC/GR) interaction plays a critical role in maintaining overall glucose homeostasis, in a number of tissues including the brain and periphery, as maintenance of systemic carbohydrate metabolism requires complex regulation between various peripheral organs in addition to the central nervous system. Subtle alterations in both cortisol secretion and/or tissue-specific reactivation of less active GCs (i.e., cortisone) to a more active form (i.e., cortisol), via the prereceptor enzyme $11 \beta$-hydroxysteroid dehydrogenase 1 (11 $\beta$-HSD1), are a possible link between GC biology and the development of insulin resistance [17] and metabolic syndrome/type 2 diabetes mellitus (T2DM) [18-20].

Due to their systemic catabolic actions, GCs increase hepatic glucose production [21], skeletal muscle protein degradation [22], and lipolysis [23]. As such, either endogenous overproduction (Cushing's disease) or exogenous elevations in GCs via therapeutic treatment are associated with major metabolic disturbances, often culminating in T2DM development, particularly in a setting of increased caloric intake (Figure 1).

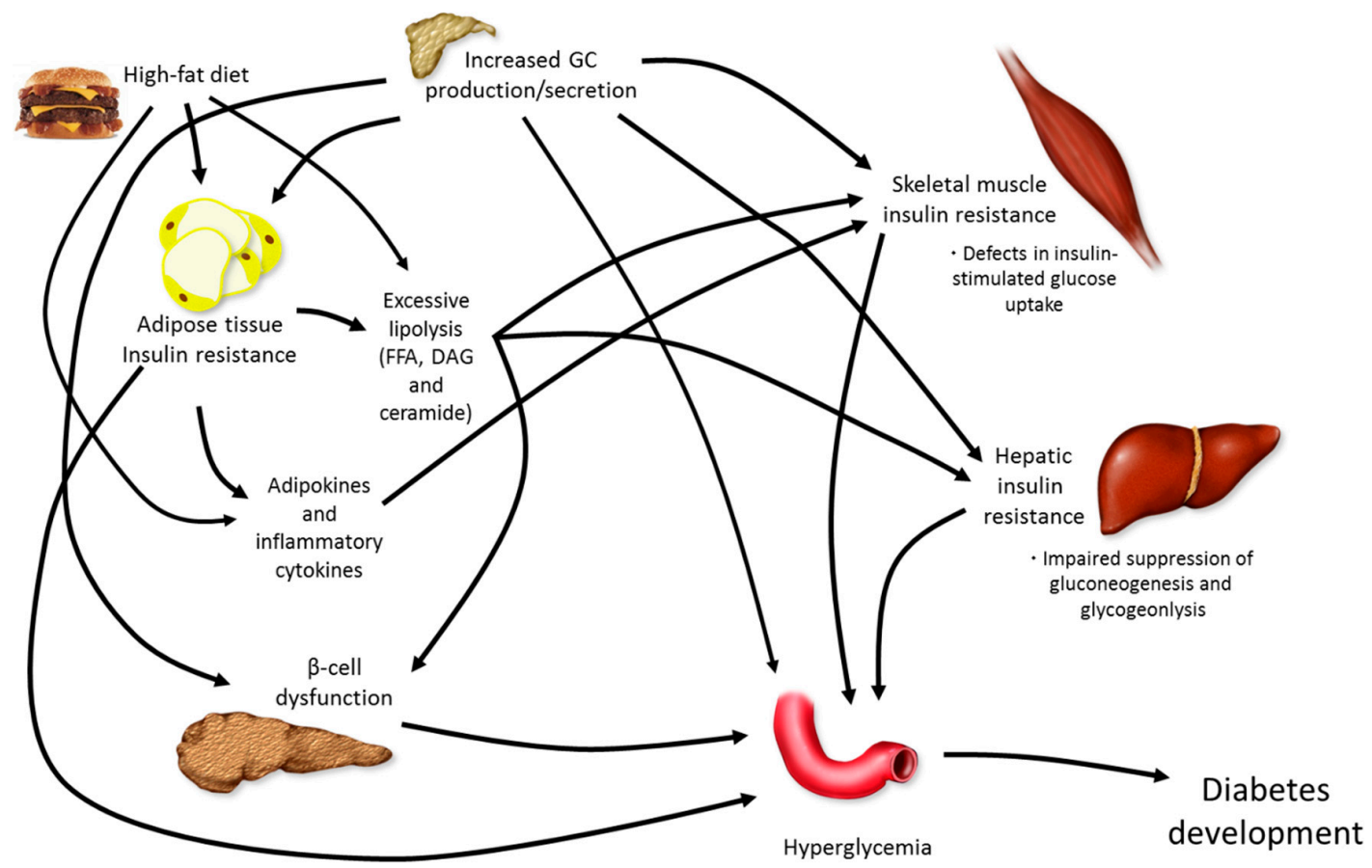

Figure 1. Pathophysiology of diabetes development. The development of overt diabetes occurs through a number of mechanisms, all of which work together to affect elevations in blood glucose, ultimately causing hyperglycemia. Glucocorticoids (GC), free fatty acids (FFA), diacylglycerol (DAG).

GCs act on the central nervous system to impact feeding behavior and physical activity patterns [14]. In rodents, elevations in GCs increase food intake in general, but tend to cause animals to consume sucrose and fats over high quality proteins or complex carbohydrates, perhaps because 
of an elevation in insulin levels [24]. Independently, chronically elevated GCs and the consumption of an energy dense diet containing saturated fat and/or simple carbohydrates cause dysregulated lipid metabolism within the skeletal muscle, liver, and adipose tissue of rodents and humans [25-28], promoting both increased visceral adipose mass accumulation and lipid deposition in various other non-adipose locations, such as the liver and skeletal muscle [10,23]. The increased ectopic fat deposition caused by an energy dense diet (in the face of relative inactivity) further propagates the detrimental aspects of the elevated catabolic action of GCs, through elevations in 11 $\beta$-HSD1 activation and/or expression [29]. These detrimental changes appear to facilitate the production of fatty acid intermediates (ceramide and diacylglycerol (DAG)) in insulin sensitive tissues, such as skeletal muscle and liver, that inhibit specific proteins involved in insulin signaling [30]. Within the skeletal muscle, elevated GC exposure (or reactivation) reduces insulin-stimulated glucose uptake through inhibition of glucose transporter 4 receptor (GLUT4) translocation [31,32], accumulation of intramuscular lipids (IMCL), and increased fatty acyl-CoA production, subsequently increasing fatty acid intermediate concentrations. Within the liver, insulin resistance manifests as increased gluconeogenesis and glycogenolysis, thereby increasing endogenous glucose production. While both GCs and increased dietary fat consumption cause the proliferation of adipose tissue and adipose tissue hypertrophy, an altered pattern of adipokine secretion (i.e., increased leptin, decreased adiponectin, increased tumor necrosis factor $\alpha$ (TNF $\alpha$ ), and elevated interleukin-6 (IL-6)) and increased lipolysis are also observed [33].

\section{Metabolic Actions of GCs within the Skeletal Muscle, Liver, and Adipose Tissue}

\subsection{GCs Cause Dyslipidemia and Inhibit Insulin Signaling Proteins within the Skeletal Muscle}

Insulin resistance, which is an impaired response of insulin-sensitive tissues to insulin signalling, is a characteristic feature of T2DM and plays a key role in the pathogenesis of the disease [34,35]. Systemic insulin sensitivity, under postprandial conditions, is mostly driven by skeletal muscle insulin sensitivity, although the liver also plays a role [36]. Hyperinsulinemia, even at physiologic levels, may actually stimulate a further worsening of insulin sensitivity in diabetes, thereby promoting a vicious cycle that places an unrelenting demand on pancreatic $\beta$-cell function [36].

Cushing's disease patients are characterized by a redistribution of body fat from peripheral subcutaneous depots, to more central abdominal regions [37]. This over activity of the HPA axis, which is also seen with obesity [38], could be causally related to insulin resistance and diabetes development through ectopic lipid deposition (i.e., muscle, liver). GCs increase whole body lipolysis which leads to elevated levels of nonesterified fatty acids (NEFA) and triglycerides (TG) [39]. Elevations in NEFA concentrations increase the risk of accumulation of IMCL, fatty acyl CoA, DAG, and ceramide which inhibit select proteins along the insulin signalling pathway [30,40], ultimately suppressing glucose uptake, primarily through the inhibition of GLUT4 translocation to the cell membrane [41]. IMCL may activate various serine kinases, such as c-Jun amino-terminal kinase (JNK) and IkB kinase (IKK), which phosphorylate serine residues on insulin receptor substrate (IRS)-1, causing a decrease in insulin signaling [42]. IRS-1 is responsible for transmitting signals from both insulin and insulin like growth factor-1 (IGF-1) through the activation of the phosphatidylinositol (PI)-3 kinase (PI3K) and MAP kinase pathways. Elevated muscle ceramide levels, as a result of excessive ectopic lipid deposition from high fat feeding (HFF) or from high GC exposure, may be key mediators of insulin resistance and muscle atrophy [43], as these lipid metabolites are capable of directly inhibiting protein kinase B (Akt) phosphorylation [44].

GCs affect several integral proteins responsible for insulin-stimulated glucose uptake. Treatment of male rats with dexamethasone (Dex), a GR agonist, causes a reduction in insulin receptor (IR) phosphorylation within skeletal muscle and subsequent inhibition of Akt phosphorylation/activity after insulin administration [45]. This deleterious effect on muscle is likely direct, since muscle insulin signaling is also suppressed with GC treatment in cultured C2C12 myotubes [46]. Chronic elevations 
of GCs in rodents have also been found to induce both a decrease in tyrosine phosphorylation and total IRS-1 protein content [47,48]. GCs also reduce PI3K activity [49], as the GR seems to compete with IRS-1 for the association of PI3K subunits p110 and p85 [31,50]. As such, activation of the GR causes a reduction in IRS-1-associated PI3K activity and subsequent Akt phosphorylation at both serine and threonine sites [31,50]. The down-regulation in Akt activity has the potential to reduce GLUT4 translocation [41], impair glycogen synthesis, and limit skeletal muscle growth, via decreased mammalian target of rapamycin (mTOR) activity [51]. GC-induced atrophy has been shown to preferentially target fast, glycolytic muscle fibers (particularly type IIx and IIb) with almost no effect in type I fibers [52]. The reduction of skeletal mass by GCs occurs through both decreased protein synthesis and increased protein breakdown [53,54]. GC excess can also impair glycogen synthesis through suppressed glycogen synthase activity [31,32,41]. In line with much of this, GR mRNA levels in the skeletal muscle of diabetic patients correlate strongly with the degree of insulin resistance, with a normalisation of GR expression following pharmacological treatment that improves insulin sensitivity [55]. Interestingly, GC provision to aged rodents has a much more profound effect on skeletal muscle morphology and insulin sensitivity when compared to GC provision to younger rats [56]. As such, the detrimental effects of GCs may be augmented with aging, which could, at least in theory, contribute to age-related sarcopenia.

\subsection{GCs Cause Hepatic Insulin Resistance and Dyslipidemia}

The liver is a major organ responsible for regulating glucose and lipid homeostasis. In the fasted state, the liver's glucose production through gluconeogenesis (GNG) and glycogenolysis (GGL) helps maintain euglycaemia. In the fed state, increased glucose uptake into the liver and the reduction in glucose production are critical components to post-prandial glucose control. With increased plasma glucose concentration, insulin is responsible for suppressing endogenous glucose production [57], while GCs and glucagon increase hepatic glucose output, which is the normal response in a fasting or catabolic state (e.g., prolonged exercise). In the presence of elevations of GCs, hepatic glucose production is elevated directly via activation of the enzymes responsible for glucose production (see below) and indirectly by promoting increased hepatic insulin resistance [58,59].

GC-induced hepatic insulin resistance results in impaired suppression of hepatic glucose production by insulin [60]. Generally, GCs exert their actions through the transcriptional regulation of a number of genes involved in hepatic carbohydrate metabolism, including glucose-6-phosphatase (G6Pase) and phosphoenolpyruvate carboxykinase (PEPCK), the rate-limiting enzymes involved in GNG [61,62]. Both of these enzymes contain a glucocorticoid response element (GRE) in their promoter regions which allows for GCs to directly modify their gene expression. As GCs are inherently catabolic, they are also capable of breaking down both protein and fat stores, ultimately increasing the availability of substrates for GNG. Moreover, similar to what is observed within the skeletal muscle, GC-induced elevation in lipid deposition in the viscera increases the supply of plasma NEFA and TG to the liver, which indirectly induces hepatic insulin resistance [63]. This accumulation of lipids within the liver, also known as hepatosteatosis, can lead to non-alcoholic fatty liver disease (NAFLD) [28], and possibly more severe liver diseases such as non-alcoholic steatohepatitis, fibrosis, cirrhosis, and cancer [64].

\subsection{GCs Increase Adipose Tissue Proliferation and Lipolysis}

It is clearly established that elevations in GCs, whether in Cushing's disease patients or through exogenous corticosteroid therapy, cause excess adiposity [65]. This finding is somewhat surprising as GCs appear to exert catabolic actions in all other metabolically active tissues (i.e., skeletal muscle, liver, and bone) [66]. Within the adipose tissue itself, however, GCs have been shown to have a contradictory role in lipid metabolism, causing both increased lipolysis and increased visceral adiposity [23]. Generally, GCs increase lipolysis in mature adipocytes through enhanced transcription and expression of the lipase proteins adipose triglyceride lipase (ATGL) and hormone sensitive lipase (HSL) [67,68], while increased central adiposity occurs through upregulation of adipose cell proliferation in addition 
to increased food consumption [69]. Whether GCs alter changes in catecholamine-stimulated lipolysis is somewhat unclear [23].

As mentioned above, $11 \beta-H S D 1$, which is predominately expressed within the liver, brain, skeletal muscle, and adipose tissue, amplifies the amount of active GCs in a given tissue, potentially increasing the exposure to increased GC activity [70]. Increased levels of 11 $\beta$-HSD1 have been observed within the adipose depots of obese individuals [71] and further research has identified that both 11 $\beta$-HSD1 [72] and GR [73] levels are much greater within the viscera when compared to the subcutaneous adipose depots. When compared to subcutaneous adipocytes, visceral adipocytes appear to have a higher affinity to GCs [74]. Increased 11ß-HSD1 expression in adipose tissue in a transgenic rodent model resulted in elevated adipose tissue GC levels, enhanced food intake, and an accumulation of visceral adiposity, along with other features of metabolic syndrome [75]. This suggests that adipose tissue-specific increases in GC action, perhaps through the upregulation of 11 $\beta$-HSD1 expression or activity, stimulates enhanced visceral fat accumulation and deteriorates whole body insulin sensitivity via direct actions within the adipose tissue.

\section{GCs and Food Intake}

\section{Impact of GCs on Brain and Feeding Behaviour}

The catabolic activity of GCs causes the mobilization of substrates from peripheral sources such as the skeletal muscle, liver, and adipose tissue. GCs are also capable of acting on the brain by modulating behaviour, autonomic, and sympathetic responses in addition to augmenting learning and memory [76]. The consumption of foods containing high fat and high sugar substances (often called "comfort foods") has been found to be proportional to circulating GCs, and corticosterone is a hormone known to stimulate food-associated drives or motivations [14,77]. GCs also stimulate insulin secretion, and along with the resultant hyperinsulinemia, this interaction of GCs with hyperinsulinemia, modulates food choice to favour sucrose and lard in rodents [5,16].

Two elegant rodent studies examined the effect of prior metabolic stress (restraint or cold stress) on the preference for "comfort foods" and the subsequent response of the HPA axis. Both studies found that "comfort" foods were preferred to standard chow, and the provision of these "comfort" foods reduced the degree of the stressor-induced sympathetic responses and lowered the basal corticotropin-releasing factor/hormone (CRF) levels within the hypothalamus [78,79]. Cushing's disease patients have been found to choose high-fat foods, when compared to individuals with normal GCs levels [80]. Moreover, elevations in catecholamines, which are also associated with heightened HPA axis activity, have been shown to increase feeding activities in rodents [81]. GCs indirectly increase feeding behaviour through the modification of neuropeptide Y (NPY) [82], the key orexigenic neurotransmitter linked to food consumption and adipose tissue deposition [83].

\section{Combining Elevations in GCs with High-Fat Feeding}

\subsection{Dexamethasone or Corticosterone Exogenous Treatment and High-Fat Feeding}

With the number of people currently taking synthetic GCs on the rise [84], it is important to fully understand the association between elevations in GC concentrations and increased dietary fat consumption. Specifically, the type of fat is critically important, as diets high in saturated fatty acids are a more potent diabetogenic stimulus than mono- and polyunsaturated fatty acids [85]. Surprisingly, very limited research has been conducted examining the potential synergistic actions of the two metabolic insults. Moreover, the effects of high quality protein intake on attenuating GC-induced muscle loss and insulin sensitivity are unknown.

In one key study, Gounarides et al. [86] examined the effect of three intraperitoneal injections of Dex over 5 days, in a diet-induced obesity (DIO) murine model of insulin resistance ( 2 months of HFD; $45 \%$ of the total calories from lard; D12451, Research Diets). The authors found that compared to 
controls, the DIO and Dex-treated mice had impaired glucose tolerance, increased food consumption, body weight, visceral adiposity, and skeletal muscle lipid deposition, in addition to a shift in lipid profile towards more saturated fats. Additional work examined the effect of HFD (enriched with 17.5\% soybean oil), adrenalectomy, and Dex treatment on the expression of adiponectin and its receptors in another complementary study [87]. GC exposure in wild-type mice is known to cause inhibition of adiponectin receptor gene expression within skeletal muscle [88], possibly affecting positive downstream consequences of adiponectin signaling in skeletal muscle, such as fatty acid oxidation and the prevention of IMCL accumulation. With the addition of a HFD following adrenalectomy and subsequent Dex treatment, both circulating adiponectin and adiponectin receptor concentrations were decreased within the skeletal muscle, suggesting one more potential deleterious metabolic effect when the two metabolic insults are combined [87]. A more recent rodent model utilizing corticosterone pellet implants, in combination with HFD (60\% of the total calories from lard, D12492, Research Diets; abbreviated to Cort-HFD) has been developed to induce a rapid diabetic phenotype in young Sprague-Dawley rats [89]. The Cort-HFD rats become severely hyperglycemic, hyperinsulinemic, and insulin resistant through the development of hepatic steatosis [90], impaired $\beta$-cell function [91], and increased lipid deposition in the viscera, liver, and skeletal muscle [89,92] (Figure 2). In another model, broiler chicks received either a HFD (enriched with $13.5 \%$ soybean oil) or low-fat diet ( $0 \%$ soybean oil; LFD) for 6 days and were then given an intracerebroventricular injection of either Dex or saline. The Dex injection, in combination with the 6 days of HFD, caused significant decreases in hypothalamic gene expression, which were not observed in any other treatment conditions [93]. What is interesting about all of these models is that with corticosterone/dexamethasone or a HFD alone, the animals do not develop the same metabolic impairments, but when the two treatment conditions are combined, the detrimental actions are dramatically amplified. These animal models seem to mimic many of the symptoms observed in patients with T2DM, and provides evidence that elevations in GCs induce diabetes development, especially if the susceptible individuals do not consume a normal low fat diet.

A)

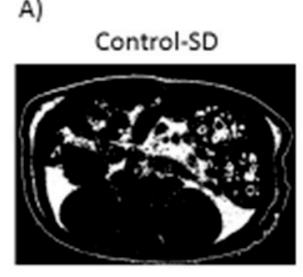

Control-HFD

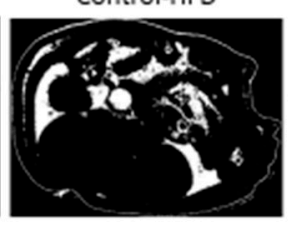

Cort- SD

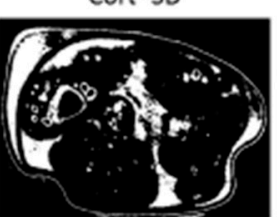

B)

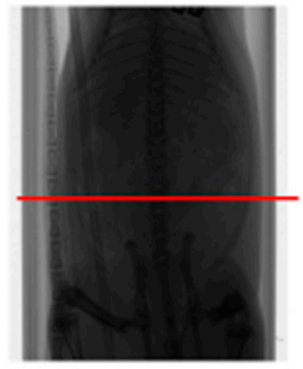

Figure 2. Micro-computed tomography shows that corticosterone and a high-fat diet caused increased abdominal fat. (A) A representation of abdominal fat from a representative rat from each group is shown; (B) A whole rat radiography with the ROI (region of interest) used. Standard diet (SD), high-fat diet (HFD), corticosterone (Cort).

Generally, the above HFD/GC overexposure models demonstrate a consistent and rapid increase in both visceral adiposity and ectopic lipid deposition (liver, muscle). It is possible that since elevations in IMCL are known to occur within 2-3 days of HFD [94], and as both GCs and a HFD cause significant IMCL accumulation, it could be proposed that the rapidity of the metabolic dysfunction, within the majority of these co-treatment models, could be attributed to the initial accumulation in IMCL. When combined with augmented tissue-specific GC activity, as 11 $\beta-H S D 1$ content is increased in the adipose tissue with HFD, the co-treatment could be both increasing visceral adiposity and active GC exposure within the adipose tissue, propagating the detrimental effects of the elevated GCs. Further work examining the mechanisms which contribute to the augmentation of the deleterious metabolic effects caused by the combination of elevations in GCs, whether exogenously or endogenously, and HFD is necessitated. 


\subsection{Chronic Stress and High-Fat Feeding}

Another methodology utilized to induce HPA activation is the chronic stress model, such as chronic social defeat stress (CSDS), restraint stress, or cold stress. Generally, when this form of GC elevation is combined with a HFD, the results are surprisingly contradictory to what is observed when Dex or corticosterone is injected or implanted exogenously. In mice exposed to both DIO and CSDS, the chronic stress actually improved the increased adiposity, body weight, and glucose intolerance observed after DIO [95]. Similarly, Wistar rats provided with a HFD and immobilized for $1 \mathrm{~h}, 5$ days/week for 15 weeks, were protected from DIO, as these animals consumed less, and when compared to the non-stressed, DIO rats, had normal glucose tolerances [96]. Clinically, this is very relevant, and needs to be further explored as it suggests that those individuals taking exogenous GC therapy are at much higher risk of further metabolic complications if consuming a diet high in fat.

\section{Role of Exercise in Offsetting the Metabolic Implications of Both Elevated GCs and High-Fat Feeding}

Regular physical activity (i.e., exercise) is widely used to control and/or treat several cardiometabolic diseases because of its compensatory and regulatory actions on a variety of organs including muscle, bone, liver, and adipose tissue. Interestingly, exercise is itself a common form of metabolic stress which stimulates the HPA axis [97] causing increased circulating GCs to mobilize fuel sources and subdue the immune system during exercise-induced muscle damage. While elevations in circulating GC levels induce insulin resistance, regular exercise enhances insulin sensitivity and causes reductions in both GR and II $\beta$-HSD1 expression within the skeletal muscle, liver, and adipose tissue [98], ultimately reducing tissue-specific GC exposure. Regular treadmill running before and during two weeks of Dex treatment improved glycogen loss [99,100], hyperinsulinemia, and muscular atrophy [100] in some muscles, as well as increasing physical capacity. When analyzed in rheumatoid arthritis patients, 24 months of dynamic strength training improved both muscle strength and physical function, without negatively impacting disease activity [101]. While others have found, in rodents, both chronic treadmill running and resistance training downregulate muscle RING-finger protein-1 (MuRF1) and atrogin-1 in atrophy induced through elevations in circulating GCs, in addition to improving glucose homeostasis [102-105]. The best form of exercise to limit GC-induced metabolic dysregulation is unknown, but typically both resistance and aerobic forms of exercise are thought to have independent and additive beneficial effects, at least in humans [106,107]. High-intensity resistance training has recently been demonstrated to attenuate dexamethasone-induced muscle atrophy in rats via up-regulation of mTOR and p70S6K and a reduction in MuFR-1 protein expression [108].

Voluntary exercise, generally considered to be aerobic, is well known to improve skeletal muscle insulin-stimulated glucose uptake [109] and insulin resistance [99], induced by GC exposure, through attenuation of reductions in specific insulin signaling proteins, including Akt and IRS-1 activity and expression. Exercise also lowers ceramide content, while at the same time improving insulin sensitivity, possibly by directing lipids into the triglyceride pool [110-112]. However, exercise training is not typically able to improve the extreme weight loss seen with dexamethasone or corticosterone treatment [113] or some of the reductions observed in angiogenesis, specifically decreased vascular endothelial growth factor (VEGF) expression [100].

Remarkably, very little is known in regard to the effect of regular exercise in rodents or humans consuming a HFD while undergoing exogenous GC treatment. To date, only three studies have investigated the therapeutic potential of exercise, predominantly aerobic exercise, in GC-treated, high-fat fed rodents. Liu et al. [114] established a mouse model which expressed a depression-like phenotype and an insulin-resistant state through the chronic treatment of corticosterone and HFD (Cort-HFD). Following 4 weeks of treadmill running, the Cort-HFD mice had improved blood glucose concentrations, decreased depression-like symptoms and overall improvements in mobility [114]. Similar results were observed in Cort-HFD treated rats following 4 weeks of voluntary wheel running. The Cort-HFD rats showed improved glucose tolerance, insulin secretion, hyperglycemia, 
hyperinsulinemia, and homeostatic model assessment of insulin resistance (HOMA-IR) values [92]. There were also specific skeletal muscle improvements, with increased glycolytic muscle mass, tibialis anterior cross-sectional area, oxidative capacity, and capillarization (Figure 3). An interesting aspect to this study was that these results were exercise volume specific, as less running correlated with a reduced amount of metabolic improvements, highlighting the fact that exercise-induced adaptations depend on the duration, intensity, and overall volume of the exercise intervention. Another study investigated the effect of Cort provision during voluntary wheel running on HFD preference [115]. Sprague-Dawley rats that were provided Cort in their drinking water had reduced HFD intake and body weight during wheel running, but interestingly no change in HFD preference. These results suggest that voluntary exercise is able to decrease the preference and overall intake of HFD in rats, and that this effect is possibly amplified when exogenous Cort is administered. Clearly, further work is required to fully elucidate all of the possible benefits associated with voluntary exercise (both resistanceand endurance-type exercise) and alterations in macronutrient content of diet (e.g., high-quality protein diet vs. high fat diet) in both humans and rodents undergoing exogenous GC therapy.

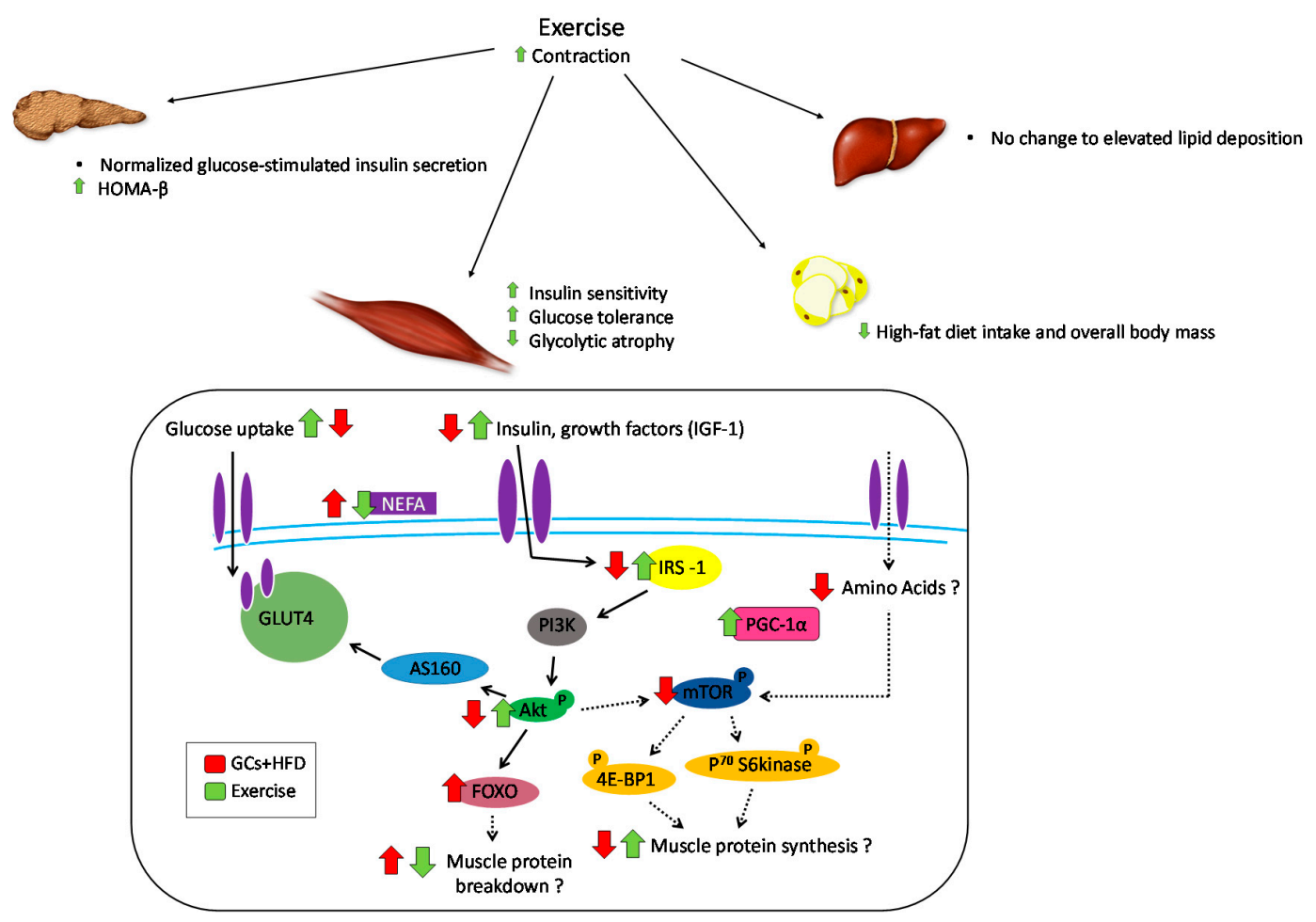

Figure 3. Counter-effects of exercise on metabolic impairments caused by elevated glucocorticoids and high-fat diet. Physical activity (treadmill running or voluntary wheel running) is capable of improving some of the metabolic effects caused by elevated glucocorticoids (GCs) and a high-fat diet (HFD), specifically within the pancreas, skeletal muscle, adipose tissue, and liver. The skeletal muscle is currently the most researched, and the majority of the benefits of exercise revolve around improvements in insulin signaling. Elevations in GCs combined with HFD cause significant metabolic effects, and further examination of exercise on the pancreas, adipose tissue, and liver is required.

\section{Conclusions}

Due to their pleiotropic consequences, GCs affect almost every tissue in the body, which increases their possible therapeutic benefits, but also intensifies likely side effects. Synthetic GCs are the predominant form of treatment for numerous inflammatory and immunological disorders, which makes the understanding the effect of diet and nutrition on their action a major clinical concern. Significant relationships exist between exogenous elevations in GC concentrations, peripheral insulin 
resistance, and diabetes development; an association which becomes magnified with the addition of a HFD. Fortunately, exercise appears to be a viable therapeutic option to offset some of the more severe metabolic side effects by improving overall glucose tolerance, skeletal muscle insulin signaling, insulin secretion, and body composition. Further research is required to fully understand the metabolic consequences of combining elevations in GCs and increased dietary fat in addition to the effect of exercise as a possible countermeasure.

Acknowledgments: Michael C. Riddell, and Emily C. Dunford were supported by the Natural Sciences and Engineering Research Council of Canada. We would like to thank Sofhia V. Ramos for completion of the Micro-computed tomographic images.

Author Contributions: Emily C. Dunford and Michael C. Riddell conceived and wrote the manuscript; Both authors have read and approved the final manuscript.

Conflicts of Interest: The authors declare no conflict of interest.

\section{References}

1. Walsh, D.; Avashia, J. Gcs in clinical oncology. Clevel. Clin. J. Med. 1992, 59, 505-515. [CrossRef]

2. Rhen, T.; Cidlowski, J.A. Anti-inflammatory action of glucocorticoids-new mechanisms for old drugs. New Engl. J. Med. 2005, 353, 1711-1723. [CrossRef] [PubMed]

3. Caporali, R.; Scire, C.A.; Todoerti, M.; Montecucco, C. The role of low dose glucocorticoids for rheumatoid arthritis in the biologic era. Clin. Exp. Rheumatol. 2013, 31, S9-S13. [PubMed]

4. Overman, R.A.; Yeh, J.Y.; Deal, C.L. Prevalence of oral glucocorticoid usage in the united states: A general population perspective. Arthritis Care Res. 2013, 65, 294-298. [CrossRef] [PubMed]

5. Walsh, L.J.; Wong, C.A.; Pringle, M.; Tattersfield, A.E. Use of oral corticosteroids in the community and the prevention of secondary osteoporosis: A cross sectional study. Br. Med. J. 1996, 313, 344-346. [CrossRef]

6. Van Staa, T.P.; Leufkens, H.G.M.; Abenhaim, L.; Begaud, B.; Zhang, B.; Cooper, C. Use of oral corticosteroids in the United Kingdom. QJM 2000, 93, 105-111. [CrossRef] [PubMed]

7. Gudbjornsson, B.; Juliusson, U.I.; Gudjonsson, F.V. Prevalence of long term steroid treatment and the frequency of decision making to prevent steroid induced osteoporosis in daily clinical practice. Ann. Rheum. Dis. 2002, 61, 32-36. [CrossRef] [PubMed]

8. Owczarek, J.; Jasinska, M.; Orszulak-Michalak, D. Drug-induced myopathies. An overview of the possible mechanisms. Pharmacol. Rep. 2005, 57, 23-34. [PubMed]

9. Stojanovska, L.; Rosella, G.; Proietto, J. Evolution of dexamethasone-induced insulin resistance in rats. Am. J. Physiol. Endocrinol. Metab. 1990, 258, E748-E756.

10. Asensio, C.; Muzzin, P.; Rohner-Jeanrenaud, F. Role of glucocorticoids in the physiopathology of excessive fat deposition and insulin resistance. Int. J. Obes. Relat. Metab. Disord. 2004, 28 (Suppl. 4), S45-S52. [CrossRef] [PubMed]

11. Pivonello, R.; De Leo, M.; Vitale, P.; Cozzolino, A.; Simeoli, C.; De Martino, M.C.; Lombardi, G.; Colao, A. Pathophysiology of diabetes mellitus in cushing's syndrome. Neuroendocrinology 2010, 92 (Suppl. 1), 77-81. [CrossRef] [PubMed]

12. Zakrzewska, K.E.; Cusin, I.; Stricker-Krongrad, A.; Boss, O.; Ricquier, D.; Jeanrenaud, B.; Rohner-Jeanrenaud, F. Induction of obesity and hyperleptinemia by central glucocorticoid infusion in the rat. Diabetes 1999, 48, 365-370. [CrossRef] [PubMed]

13. Dallman, M.F. Stress-induced obesity and the emotional nervous system. Trends Endocrinol. Metab. 2010, 21, 159-165. [CrossRef] [PubMed]

14. Dallman, M.F.; Pecoraro, N.C.; la Fleur, S.E. Chronic stress and comfort foods: Self-medication and abdominal obesity. Brain Behav. Immun. 2005, 19, 275-280. [CrossRef] [PubMed]

15. Tomlinson, J.W.; Stewart, P.M. Modulation of glucocorticoid action and the treatment of type-2 diabetes. Best Pract. Res. Clin. Endocrinol. Metab. 2007, 21, 607-619. [CrossRef] [PubMed]

16. Dallman, M.F.; Warne, J.P.; Foster, M.T.; Pecoraro, N.C. Glucocorticoids and insulin both modulate caloric intake through actions on the brain. J. Physiol. 2007, 583, 431-436. [CrossRef] [PubMed]

17. Stimson, R.H.; Walker, B.R. The role and regulation of $11 \beta$-hydroxysteroid dehydrogenase type 1 in obesity and the metabolic syndrome. Horm. Mol. Biol. Clin. Investig. 2013, 15, 37-48. [CrossRef] [PubMed] 
18. Björntorp, P.; Holm, G.; Rosmond, R. Hypothalamic arousal, insulin resistance and type 2 diabetes mellitus. Diabet. Med. 1999, 16, 373-383. [CrossRef] [PubMed]

19. Morgan, S.A.; McCabe, E.L.; Gathercole, L.L.; Hassan-Smith, Z.K.; Larner, D.P.; Bujalska, I.J.; Stewart, P.M.; Tomlinson, J.W.; Lavery, G.G. 11ß-hsd1 is the major regulator of the tissue-specific effects of circulating glucocorticoid excess. Proc. Natl. Acad. Sci. USA 2014, 111, E2482-E2491. [CrossRef] [PubMed]

20. Anagnostis, P.; Katsiki, N.; Adamidou, F.; Athyros, V.G.; Karagiannis, A.; Kita, M.; Mikhailidis, D.P. 11beta-hydroxysteroid dehydrogenase type 1 inhibitors: Novel agents for the treatment of metabolic syndrome and obesity-related disorders? Metab. Clin. Exp. 2013, 62, 21-33. [CrossRef] [PubMed]

21. Yuen, K.C.; Chong, L.E.; Riddle, M.C. Influence of glucocorticoids and growth hormone on insulin sensitivity in humans. Diabet. Med. 2013, 30, 651-663. [CrossRef] [PubMed]

22. Stellato, C. Post-transcriptional and nongenomic effects of glucocorticoids. Proc. Am. Thorac. Soc. 2004, 1, 255-263. [CrossRef] [PubMed]

23. Peckett, A.J.; Wright, D.C.; Riddell, M.C. The effects of glucocorticoids on adipose tissue lipid metabolism. Metab. Clin. Exp. 2011, 60, 1500-1510. [CrossRef] [PubMed]

24. La Fleur, S.E.; Akana, S.F.; Manalo, S.L.; Dallman, M.F. Interaction between corticosterone and insulin in obesity: Regulation of lard intake and fat stores. Endocrinology 2004, 145, 2174-2185. [CrossRef] [PubMed]

25. Koyama, K.; Chen, G.; Lee, Y.; Unger, R.H. Tissue triglycerides, insulin resistance, and insulin production: Implications for hyperinsulinemia of obesity. Am. J. Physiol. 1997, 273, E708-E713. [PubMed]

26. Pan, D.A.; Lillioja, S.; Kriketos, A.D.; Milner, M.R.; Baur, L.A.; Bogardus, C.; Jenkins, A.B.; Storlien, L.H. Skeletal muscle triglyceride levels are inversely related to insulin action. Diabetes 1997, 46, 983-988. [CrossRef] [PubMed]

27. Rose, A.J.; Vegiopoulos, A.; Herzig, S. Role of glucocorticoids and the glucocorticoid receptor in metabolism: Insights from genetic manipulations. J. Steroid Biochem. Mol. Biol. 2010, 122, 10-20. [CrossRef] [PubMed]

28. Asrih, M.; Jornayvaz, F.R. Diets and nonalcoholic fatty liver disease: The good and the bad. Clin. Nutr. 2014, 33, 186-190. [CrossRef] [PubMed]

29. Cooper, M.S.; Stewart, P.M. 11beta-hydroxysteroid dehydrogenase type 1 and its role in the hypothalamuspituitary-adrenal axis, metabolic syndrome, and inflammation. J. Clin. Endocrinol. Metab. 2009, 94, 4645-4654. [CrossRef] [PubMed]

30. Bosma, M.; Kersten, S.; Hesselink, M.K.; Schrauwen, P. Re-evaluating lipotoxic triggers in skeletal muscle: Relating intramyocellular lipid metabolism to insulin sensitivity. Prog. Lipid Res. 2012, 51, 36-49. [CrossRef] [PubMed]

31. Buren, J.; Lai, Y.C.; Lundgren, M.; Eriksson, J.W.; Jensen, J. Insulin action and signalling in fat and muscle from dexamethasone-treated rats. Arch. Biochem. Biophys. 2008, 474, 91-101. [CrossRef] [PubMed]

32. Dimitriadis, G.; Leighton, B.; Parry-Billings, M.; Sasson, S.; Young, M.; Krause, U.; Bevan, S.; Piva, T.; Wegener, G.; Newsholme, E.A. Effects of gc excess on the sensitivity of glucose transport and metabolism to insulin in rat skeletal muscle. J. Biochem. 1997, 321, 707-712. [CrossRef]

33. Stefanyk, L.E.; Dyck, D.J. The interaction between adipokines, diet and exercise on muscle insulin sensitivity. Curr. Opin. Clin. Nutr. Metab. Care 2010, 13, 255-259. [CrossRef] [PubMed]

34. DeFronzo, R.A. Pathogenesis of type 2 diabetes mellitus. Med. Clin. N. Am. 2004, 88, 787-835. [CrossRef] [PubMed]

35. DeFronzo, R.A.; Tripathy, D. Skeletal muscle insulin resistance is the primary defect in type 2 diabetes. Diabetes Care 2009, 32 (Suppl. 2), S157-S163. [CrossRef] [PubMed]

36. Kelley, D.E.; Goodpaster, B.H. Skeletal muscle triglyceride an aspect of regional adiposity and insulin resistance. Diabetes Care 2001, 24, 933-941. [CrossRef] [PubMed]

37. Arnaldi, G.; Scandali, V.M.; Trementino, L.; Cardinaletti, M.; Appolloni, G.; Boscaro, M. Pathophysiology of dyslipidemia in cushing's syndrome. Neuroendocrinology 2010, 92, 86-90. [CrossRef] [PubMed]

38. Rutters, F.; Nieuwenhuizen, A.G.; Lemmens, S.G.T.; Born, J.M.; Westerterp-Plantenga, M.S. Hypothalamic-pituitary-adrenal (hpa) axis functioning in relation to body fat distribution. Clin. Endocrinol. 2010, 72, 738-743. [CrossRef] [PubMed]

39. Wajchenberg, B.L. Subcutaneous and visceral adipose tissue: Their relation to the metabolic syndrome. Endocr. Rev. 2000, 21, 697-738. [CrossRef] [PubMed] 
40. Singh, M.K.; Krisan, A.D.; Crain, A.M.; Collins, D.E.; Yaspelkis, B.B. High-fat diet and leptin treatment alter skeletal muscle insulin-stimulated phosphatidylinositol 3-kinase activity and glucose transport. Metab. Clin. Exp. 2003, 52, 1196-1205. [CrossRef]

41. Weinstein, S.P.; Wilson, C.M.; Pritsker, A.; Cushman, S.W. Dexamethasone inhibits insulin-stimulated recruitment of glut4 to the cell surface in rat skeletal muscle. Metab. Clin. Exp. 1998, 47, 3-6. [CrossRef]

42. Perseghin, G.; Petersen, K.; Shulman, G.I. Cellular mechanism of insulin resistance: Potential links with inflammation. Int. J. Obes. Relat. Metab. Disord. 2003, 27 (Suppl. 3), S6-S11. [CrossRef] [PubMed]

43. Dirks-Naylor, A.J.; Griffiths, C.L. Glucocorticoid-induced apoptosis and cellular mechanisms of myopathy. J. Steroid Biochem. Mol. Biol. 2009, 117, 1-7. [CrossRef] [PubMed]

44. Chavez, J.A.; Knotts, T.A.; Wang, L.P.; Li, G.; Dobrowsky, R.T.; Florant, G.L.; Summers, S.A. A role for ceramide, but not diacylglycerol, in the antagonism of insulin signal transduction by saturated fatty acids. J. Biol. Chem. 2003, 278, 10297-10303. [CrossRef] [PubMed]

45. Long, W.; Barrett, E.J.; Wei, L.; Liu, Z. Adrenalectomy enhances the insulin sensitivity of muscle protein synthesis. Am. J. Physiol. Endocrinol. Metab. 2003, 284, E102-E109. [CrossRef] [PubMed]

46. Sandri, M.; Sandri, C.; Gilbert, A.; Skurk, C.; Calabria, E.; Picard, A.; Walsh, K.; Schiaffino, S.; Lecker, S.H.; Goldberg, A.L. Foxo transcription factors induce the atrophy-related ubiquitin ligase atrogin-1 and cause skeletal muscle atrophy. Cell 2004, 117, 399-412. [CrossRef]

47. Brown, P.D.; Badal, S.; Morrison, S.; Ragoobirsingh, D. Acute impairment of insulin signalling by dexamethasone in primary cultured rat skeletal myocytes. Mol. Cell. Biochem. 2007, 297, 171-177. [CrossRef] [PubMed]

48. Girogino, F.; Almahfouz, A.; Goodyear, L.J.; Smith, R.J. Glucocorticoid regulation of insulin receptor and substrate irs-1 tyrosine phosphorylation in rat skeletal muscle in vivo. J. Clin. Investig. 1993, 91, 2020-2030. [CrossRef] [PubMed]

49. Saad, M.J.A.; Folli, F.; Khan, J.A.; Kahn, C.R. Modulation of ir, irs-1 and pi3-k in liver and muscle of dexamethasone-treated rats. J. Clin. Investig. 1993, 92, 2065-2072. [CrossRef] [PubMed]

50. Buren, J.; Liu, H.X.; Jensen, J.; Eriksson, J.W. Dexamethasone impairs insulin signalling and glucose transport by depletion of irs-1, pi3k and pkb. Eur. J. Endocrinol. 2002, 146, 419-429. [CrossRef] [PubMed]

51. Shimizu, N.; Yoshikawa, N.; Ito, N.; Maruyama, T.; Suzuki, Y.; Takeda, S.-i.; Nakae, J.; Tagata, Y.; Nishitani, S.; Takehana, K.; et al. Crosstalk between glucocorticoid receptor and nutritional sensor mtor in skeletal muscle. Cell Metab. 2011, 13, 170-182. [CrossRef] [PubMed]

52. Wang, Y.; Pessin, J.E. Mechanisms for fiber-type specificity of skeletal muscle atrophy. Curr. Opin. Clin. Nutr. Metab. Care 2013, 16, 243-250. [CrossRef] [PubMed]

53. Schakman, O.; Gilson, H.; Thissen, J.P. Mechanisms of glucocorticoid-induced myopathy. J. Endocrinol. 2008, 197, 1-10. [CrossRef] [PubMed]

54. Goldberg, A.L.; Tischler, M.; DeMartino, G.; Griffin, G. Hormonal regulation of protein degradation and synthesis in skeletal muscle. Fed. Proc. 1980, 39, 31-36. [PubMed]

55. Whorwood, C.B.; Donovan, S.J.; Flanagan, D.; Phillips, D.I.W.; Byrne, C.D. Increased glucocorticoid receptor expression in human skeletal muscle cells may contribute to the pathogenesis of the metabolic syndrome. Diabetes 2002, 51, 1066-1075. [CrossRef] [PubMed]

56. Barbera, M.; Fierabracci, V.; Novelli, M.; Bombara, M.; Masiello, P.; Bergamini, E.; De Tata, V. Dexamethasone-induced insulin resistance and pancreatic adaptive response in aging rats are not modified by oral vanadyl sulfate treatment. Eur. J. Endocrinol. 2001, 145, 799-806. [CrossRef] [PubMed]

57. Barthel, A.; Schmoll, D. Novel concepts in insulin regulation of hepatic gluconeogenesis. Am. J. Physiol. Endocrinol. Metab. 2003, 285, E685-E692. [CrossRef] [PubMed]

58. Andrews, R.C.; Walker, B.R. Glucocorticoids and insulin resistance: Old hormones, new targets. Clin. Sci. 1999, 96, 513-523. [CrossRef] [PubMed]

59. McMahon, M.; Gerich, J.; Rizza, R. Effects of glucocorticoids on carbohydrate metabolism. Diabetes Metab. Rev. 1988, 4, 17-30. [CrossRef] [PubMed]

60. Rizza, R.A.; Mandarino, L.J.; Gerich, J.E. Cortisol-induced insulin resistance in man: Impaired suppression of glucose production and stimulation of glucose utilization due to a postreceptor defect of insulin action. J. Clin. Endocrinol. Metab. 1982, 54, 131-138. [CrossRef] [PubMed] 
61. Kooi, B.T.V.; Onuma, H.; Oeser, J.K.; Svitek, C.A.; Allen, S.R.; Kooi, C.W.V.; Chazin, W.J.; O’Brien, R.M. The glucose-6-phosphatase catalytic subunit gene promoter contains both positive and negative glucocorticoid response elements. Mol. Endocrinol. 2005, 19, 3001-3022. [CrossRef] [PubMed]

62. Jin, J.Y.; DuBois, D.C.; Almon, R.R.; Jusko, W.J. Receptor/gene-mediated pharmacodynamic effects of methylprednisolone on phosphoenolpyruvate carboxykinase regulation in rat liver. J. Pharmacol. Exp. Ther. 2004, 309, 328-339. [CrossRef] [PubMed]

63. Parekh, S.; Anania, F.A. Abnormal lipid and glucose metabolism in obesity: Implications for nonalcoholic fatty liver disease. Gastroenterology 2007, 132, 2191-2207. [CrossRef] [PubMed]

64. Tiniakos, D.G.; Vos, M.B.; Brunt, E.M. Nonalcoholic fatty liver disease: Pathology and pathogenesis. Annu. Rev. Pathol. Mech. Dis. 2010, 5, 145-171. [CrossRef] [PubMed]

65. Stewart, P.M.; Petersenn, S. 3 rationale for treatment and therapeutic options in cushing's disease. Best Pract. Res. Clin. Endocrinol. Metab. 2009, 23, S15-S22. [CrossRef]

66. Abad, V.; Chrousos, G.P.; Reynolds, J.C.; Nieman, L.K.; Hill, S.C.; Weinstein, R.S.; and Leong, G.M. Glucocorticoid excess during adolescence leads to a major persistent deficit in bone mass and an increase in central body fat. J. Bone Miner. Res. 2001, 16, 1879-1885. [CrossRef] [PubMed]

67. Xu, C.; He, J.; Jiang, H.; Zu, L.; Zhai, W.; Pu, S.; Xu, G. Direct effect of glucocorticoids on lipolysis in adipocytes. Mol. Endocrinol. 2009, 23, 1161-1170. [CrossRef] [PubMed]

68. Campbell, J.E.; Peckett, A.J.; D'souza, A.M.; Hawke, T.J.; Riddell, M.C. Adipogenic and lipolytic effects of chronic glucocorticoid exposure. Am. J. Physiol. Cell Physiol. 2011, 300, C198-C209. [CrossRef] [PubMed]

69. Lee, M.-J.; Pramyothin, P.; Karastergiou, K.; Fried, S.K. Deconstructing the roles of glucocorticoids in adipose tissue biology and the development of central obesity. Biochim. Biophys. Acta 2014, 1842, 473-481. [CrossRef] [PubMed]

70. Akiyama, N.; Akiyama, Y.; Kato, H.; Kuroda, T.; Ono, T.; Imagawa, K.; Asakura, K.; Shinosaki, T.; Murayama, T.; Hanasaki, K. Pharmacological evaluation of adipose dysfunction via 11beta-hydroxysteroid dehydrogenase type 1 in the development of diabetes in diet-induced obese mice with cortisone pellet implantation. J. Pharmacol. Exp. Ther. 2014, 349, 66-74. [CrossRef] [PubMed]

71. Desbriere, R.; Vuaroqueaux, V.; Achard, V.; Boullu-Ciocca, S.; Labuhn, M.; Dutour, A.; Grino, M. $11 \beta$-hydroxysteroid dehydrogenase type $1 \mathrm{mrna}$ is increased in both visceral and subcutaneous adipose tissue of obese patients. Obesity 2006, 14, 794-798. [CrossRef] [PubMed]

72. Bujalska, I.J.; Kumar, S.; Stewart, P.M. Does central obesity reflect "cushing's disease of the omentum"? Lancet 1997, 349, 1210-1213. [CrossRef]

73. Rebuffé-Scrive, M.; Brönnegard, M.; Nilsson, A.; Eldh, J.; Gustafsson, J.-A.; Björntorp, P. Steroid hormone receptors in human adipose tissues. J. Clin. Endocrinol. Metab. 1990, 71, 1215-1219. [CrossRef] [PubMed]

74. Sjögren, J.; Weck, M.; Nilsson, A.; Ottosson, M.; Björntorp, P. Glucocorticoid hormone binding to rat adipocytes. Biochim. Biophys. Acta 1994, 1224, 17-21. [CrossRef]

75. Masuzaki, H.; Paterson, J.; Shinyama, H.; Morton, N.M.; Mullins, J.J.; Seckl, J.R.; Flier, J.S. A transgenic model of visceral obesity and the metabolic syndrome. Science 2001, 294, 2166-2170. [CrossRef] [PubMed]

76. Pecoraro, N.; Dallman, M.F.; Warne, J.P.; Ginsberg, A.B.; Laugero, K.D.; la Fleur, S.E.; Houshyar, H.; Gomez, F.; Bhargava, A.; Akana, S.F. From malthus to motive: How the hpa axis engineers the phenotype, yoking needs to wants. Prog. Neurobiol. 2006, 79, 247-340. [CrossRef] [PubMed]

77. Kuo, L.E.; Czarnecka, M.; Kitlinska, J.B.; Tilan, J.U.; Kvetňanský, R.; Zukowska, Z. Chronic stress, combined with a high-fat/high-sugar diet, shifts sympathetic signaling toward neuropeptide y and leads to obesity and the metabolic syndrome. Ann. N. Y. Acad. Sci. 2008, 1148, 232-237. [CrossRef] [PubMed]

78. Bell, M.E.; Bhargava, A.; Soriano, L.; Laugero, K.; Akana, S.F.; Dallman, M.F. Sucrose intake and corticosterone interact with cold to modulate ingestive behaviour, energy balance, autonomic outflow and neuroendocrine responses during chronic stress. J. Neuroendocrinol. 2002, 14, 330-342. [CrossRef] [PubMed]

79. Pecoraro, N.; Reyes, F.; Gomez, F.; Bhargava, A.; Dallman, M.F. Chronic stress promotes palatable feeding, which reduces signs of stress: Feedforward and feedback effects of chronic stress. Endocrinology 2004, 145, 3754-3762. [CrossRef] [PubMed]

80. Castonguay, T.W. Glucocorticoids as modulators in the control of feeding. Brain Res. Bull. 1991, $27,423-428$. [CrossRef] 
81. Leibowitz, S.F.; Sladek, C.; Spencer, L.; Tempel, D. Neuropeptide y, epinephrine and norepinephrine in the paraventricular nucleus: Stimulation of feeding and the release of corticosterone, vasopressin and glucose. Brain Res. Bull. 1988, 21, 905-912. [CrossRef]

82. Epel, E.; Lapidus, R.; McEwen, B.; Brownell, K. Stress may add bite to appetite in women: A laboratory study of stress-induced cortisol and eating behavior. Psychoneuroendocrinology 2001, 26, 37-49. [CrossRef]

83. Strack, A.M.; Schwartz, M.W.; Dallman, M.F. Glucocorticoids and insulin: Reciprocal signals for energy balance. Am. J. Physiol. 1995, 268, R141-R149.

84. Targownik, L.E.; Nugent, Z.; Singh, H.; Bernstein, C.N. Prevalence of and outcomes associated with corticosteroid prescription in inflammatory bowel disease. Inflamm. Bowel Dis. 2014, 20, 622-630. [CrossRef] [PubMed]

85. Deer, J.; Koska, J.; Ozias, M.; Reaven, P. Dietary models of insulin resistance. Metab. Clin. Exp. 2015, 64, 163-171. [CrossRef] [PubMed]

86. Gounarides, J.S.; Korach-Andre, M.; Killary, K.; Argentieri, G.; Turner, O.; Laurent, D. Effect of dexamethasone on glucose tolerance and fat metabolism in a diet-induced obesity mouse model. Endocrinology 2008, 149, 758-766. [CrossRef] [PubMed]

87. De Oliveira, C.; de Mattos, A.B.; Biz, C.; Oyama, L.M.; Ribeiro, E.B.; do Nascimento, C.M.O. High-fat diet and glucocorticoid treatment cause hyperglycemia associated with adiponectin receptor alterations. Lipids Health Dis. 2011, 10. [CrossRef] [PubMed]

88. De Oliveira, C.; Iwanaga-Carvalho, C.; Mota, J.F.; Oyama, L.M.; Ribeiro, E.B.; Oller do Nascimento, C.M. Effects of adrenal hormones on the expression of adiponectin and adiponectin receptors in adipose tissue, muscle and liver. Steroids 2011, 76, 1260-1267. [CrossRef] [PubMed]

89. Shpilberg, Y.; Beaudry, J.L.; D'Souza, A.; Campbell, J.E.; Peckett, A.; Riddell, M.C. A rodent model of rapid-onset diabetes induced by glucocorticoids and high-fat feeding. Dis. Mod. Mech. 2012, 5, 671-680. [CrossRef] [PubMed]

90. D'Souza, A.M.; Beaudry, J.L.; Szigiato, A.; Trumble, S.J.; Snook, L.A.; Bonen, A.; Giacca, A.; Riddell, M.C. Consumption of a high-fat diet rapidly exacerbates the development of fatty liver disease that occurs with chronically elevated glucocorticoids. Am. J. Physiol. Gastrointest. Liver Physiol. 2011, 302, G850-G863. [CrossRef] [PubMed]

91. Beaudry, J.L.; D'Souza A, M.; Teich, T.; Tsushima, R.; Riddell, M.C. Exogenous glucocorticoids and a high-fat diet cause severe hyperglycemia and hyperinsulinemia and limit islet glucose responsiveness in young male sprague-dawley rats. Endocrinology 2013, 154, 3197-3208. [CrossRef] [PubMed]

92. Beaudry, J.L.; Dunford, E.C.; Leclair, E.; Mandel, E.R.; Peckett, A.J.; Haas, T.L.; Riddell, M.C. Voluntary exercise improves metabolic profile in high-fat fed glucocorticoid-treated rats. J. Appl. Physiol. 2015, 118, 1331-1343. [CrossRef] [PubMed]

93. Liu, L.; Wang, X.; Jiao, H.; Zhao, J.; Lin, H. Glucocorticoids inhibited hypothalamic target of rapamycin in high fat diet-fed chicks. Poult Sci. 2015, 94, 2221-2227. [CrossRef] [PubMed]

94. Bonen, A.; Jain, S.S.; Snook, L.A.; Han, X.X.; Yoshida, Y.; Buddo, K.H.; Lally, J.S.; Pask, E.D.; Paglialunga, S.; Beaudoin, M.S.; et al. Extremely rapid increase in fatty acid transport and intramyocellular lipid accumulation but markedly delayed insulin resistance after high fat feeding in rats. Diabetologia 2015, 58, 2381-2391. [CrossRef] [PubMed]

95. Balsevich, G.; Uribe, A.; Wagner, K.V.; Hartmann, J.; Santarelli, S.; Labermaier, C.; Schmidt, M.V. Interplay between diet-induced obesity and chronic stress in mice: Potential role of fkbp51. J. Endocrinol. 2014, 222, 15-26. [CrossRef] [PubMed]

96. Bruder-Nascimento, T.; Campos, D.H.S.; Alves, C.; Thomaz, S.; Cicogna, A.C.; Cordellini, S. Effects of chronic stress and hfd on metabolic and nutritional parameters in wistar rats. Arq. Bras. Endocrinol. Metab. 2013, 57, 642-649. [CrossRef]

97. Campbell, J.E.; Rakhshani, N.; Fediuc, S.; Bruni, S.; Riddell, M.C. Voluntary wheel running initially increases adrenal sensitivity to adrenocorticotrophic hormone, which is attenuated with long-term training. J. Appl. Physiol. 2009, 106, 66-72. [CrossRef] [PubMed]

98. Coutinho, A.E.; Campbell, J.E.; Fediuc, S.; Riddell, M.C. Effect of voluntary exercise on peripheral tissue glucocorticoid receptor content and the expression and activity of 11beta-hsd1 in the syrian hamster. J. Appl. Physiol. 2006, 100, 1483-1488. [CrossRef] [PubMed] 
99. Jung, H.L.; Kang, H.Y. Effects of endurance exercise and high-fat diet on insulin resistance and ceramide contents of skeletal muscle in sprague-dawley rats. Korean Diabetes J. 2010, 34, 244-252. [CrossRef] [PubMed]

100. Barel, M.; Perez, O.A.; Giozzet, V.A.; Rafacho, A.; Bosqueiro, J.R.; do Amaral, S.L. Exercise training prevents hyperinsulinemia, muscular glycogen loss and muscle atrophy induced by dexamethasone treatment. Eur. J. Appl. Physiol. 2010, 108, 999-1007. [CrossRef] [PubMed]

101. Hakkinen, A.; Sokka, T.; Kotaniemi, A.; Hannonen, P. A randomized two-year study of the effects of dynamic strength training on muscle strength, disease activity, functional capacity, and bone mineral density in early rheumatoid arthritis. Arthritis Rheum. 2001, 44, 515-522. [CrossRef]

102. Al-Nassan, S.; Fujita, N.; Kondo, H.; Murakami, S.; Fujino, H. Chronic exercise training down-regulates tnf-alpha and atrogin-1/mafbx in mouse gastrocnemius muscle atrophy induced by hindlimb unloading. Acta Histochem. Cytochem. 2012, 45, 343-349. [CrossRef] [PubMed]

103. Hickson, R.C.; Davis, J.R. Partial prevention of glucocorticoid-induced muscle atrophy by endurance training. Am. J. Physiol. 1981, 241, E226-E232. [PubMed]

104. Macedo, A.G.; Krug, A.L.; Herrera, N.A.; Zago, A.S.; Rush, J.W.; Amaral, S.L. Low-intensity resistance training attenuates dexamethasone-induced atrophy in the flexor hallucis longus muscle. J. Steroid Biochem. Mol. Biol. 2014, 143, 357-364. [CrossRef] [PubMed]

105. Nicastro, H.; Zanchi, N.E.; da Luz, C.R.; de Moraes, W.M.; Ramona, P.; de Siqueira Filho, M.A.; Chaves, D.F.; Medeiros, A.; Brum, P.C.; Dardevet, D.; et al. Effects of leucine supplementation and resistance exercise on dexamethasone-induced muscle atrophy and insulin resistance in rats. Nutrition 2012, 28, 465-471. [CrossRef] [PubMed]

106. Alberga, A.S.; Prud'homme, D.; Sigal, R.J.; Goldfield, G.S.; Hadjiyannakis, S.; Phillips, P.; Malcolm, J.; Ma, J.; Doucette, S.; Gougeon, R.; et al. Effects of aerobic training, resistance training, or both on cardiorespiratory and musculoskeletal fitness in adolescents with obesity: The hearty trial. Appl. Physiol. Nutr. Metab. 2015, 41, 255-265. [CrossRef] [PubMed]

107. Armstrong, M.J.; Colberg, S.R.; Sigal, R.J. Moving beyond cardio: The value of resistance training, balance training, and other forms of exercise in the management of diabetes. Diabetes Spectr. 2015, 28, 14-23. [CrossRef] [PubMed]

108. Krug, A.; Macedo, A.; Zago, A.; Rush, J.; Santos, C.; Amaral, S. High-intensity resistance training attenuates dexamethasone-induced muscle atrophy. Muscle Nerv. 2015, 53, 779-788. [CrossRef] [PubMed]

109. Holten, M.K.; Zacho, M.; Gastor, M.; Juel, C.; Wojtaszewski, J.F.P.; Dela, F. Strength training increases insulin-mediated glucose uptake, glut 4 content and insulin signaling in skeletal muscle in patients with t2dm. Diabetes 2004, 53, 294-305. [CrossRef] [PubMed]

110. Chavez, J.A.; Summers, S.A. A ceramide-centric view of insulin resistance. Cell Metab. 2012, 15, 585-594. [CrossRef] [PubMed]

111. Dube, J.J.; Amati, F.; Toledo, F.G.; Stefanovic-Racic, M.; Rossi, A.; Coen, P.; Goodpaster, B.H. Effects of weight loss and exercise on insulin resistance, and intramyocellular triacylglycerol, diacylglycerol and ceramide. Diabetologia 2011, 54, 1147-1156. [CrossRef] [PubMed]

112. Amati, F.; Dube, J.J.; Alvarez-Carnero, E.; Edreira, M.M.; Chomentowski, P.; Coen, P.M.; Switzer, G.E.; Bickel, P.E.; Stefanovic-Racic, M.; Toledo, F.G.; et al. Skeletal muscle triglycerides, diacylglycerols, and ceramides in insulin resistance: Another paradox in endurance-trained athletes? Diabetes 2011, 60, 2588-2597. [CrossRef] [PubMed]

113. Dionísio, T.; Louzada, J.; Viscelli, B.; Dionísio, E.; Martuscelli, A.; Barel, M.; Perez, O.; Bosqueiro, J.R.; Brozoski, D.; Santos, C. Aerobic training prevents dexamethasone-induced peripheral insulin resistance. Horm. Metab. Res. 2014, 46, 484-489. [CrossRef] [PubMed]

114. Liu, W.; Zhai, X.; Li, H.; Ji, L. Depression-like behaviors in mice subjected to co-treatment of high-fat diet and corticosterone are ameliorated by aicar and exercise. J. Affect. Disord. 2014, 156, 171-177. [CrossRef] [PubMed]

115. Boersma, G.J.; Tamashiro, K.L.; Moran, T.H.; Liang, N.-C. Corticosterone administration in drinking water decreases high-fat diet intake but not preference in male rats. Am. J. Physiol. 2016, 310, R733-R743. [CrossRef] [PubMed]

(C) 2016 by the authors; licensee MDPI, Basel, Switzerland. This article is an open access article distributed under the terms and conditions of the Creative Commons Attribution (CC-BY) license (http://creativecommons.org/licenses/by/4.0/). 